\title{
Risk analysis of GM crops technology in China: Modeling and governance
}

\author{
Jin Hong ${ }^{1}$, Wentao $\mathrm{Yu}^{1}$, Dora Marinova ${ }^{2}$ and Xiumei Guo ${ }^{2}$ \\ ${ }^{1}$ Management School, University of Science and Technology of China \\ ${ }^{2}$ Curtin University Sustainability Policy (CUSP) Institute, Curtin University \\ Email: hongjin@ustc.edu.cn
}

\begin{abstract}
Despite the fact that in the last decade the genetically modified (GM) food technology has produced a major change in the agricultural sector worldwide, the safety of genetically engineered crops continues to be a highly controversial issue. This paper aims at analyzing risks management of GM crops technology in China, such as risk classification, risk generating mechanisms and its governance. Drawing on both general situation of GM crops technology and extensive academic research concerning its safety, we seek to create a three-dimensional model capable of analyzing the extent of harm associated with GM crops technology risks. On the basis of this framework, the risk of GM crops technology can be divided into eight types, depending on the high or low risks levels associated with social harm, technology maturity and economic outcomes. The paper shows that China is currently located in the high risk zone of this model, where the high technological uncertainty associated with the high potential for social harm shows the urgency for better governance. In order to tackle this, the article introduces the Actor-Network Theory (ANT) as a useful tool to explore the risk assessment and governance of GM crops technology in China. It reveals that the Chinese Government is situated in Obligatory Passage Point (OPP) which is the cardinal node in the network. Its administrative sections play different roles by their respective status in the stages of introducing, creating interest, participating in development and overall support for any new technology. Hence in the case of GM technology, the Chinese government can construct an efficient governance mechanism which should be able to balance actors' interests and reduce or avoid risks induced by GM crops technology in China.
\end{abstract}

Key words: Genetically modified; GM food; risk management; three-dimension model; actor-network theory 


\section{INTRODUCTION}

The development of the world's agriculture has so far experienced two green revolutions. The first started in the 1940s and was aimed at changing the seeds while the second is the agricultural technology revolution focused on genetically modified (GM) technology which appears to be dominating the 21 st century. The GM crops technology refers to the recombinant DNA technology which can transfer external DNA from one crop to another and hence achieve a new technology with new characteristics. This technology has advantages of decreasing the usage of chemicals and fertilizers and at the same time increasing the agricultural production (Zhang et al., 2002). However, according to Rønning et al. (2003), there are many potential risks associated with GM crops, including unexpected concentrations and repetitive sequences of the exogenous genes.

The development of GM technology on the one hand is aimed at delivering economic, social and environmental benefits, but on the other it may be threatening to the ecology, human health and social security. A lot of research has already been carried out, including Paarlberg et al (2000) who examined public policy attitudes towards GM technologies and Rogers (2001) who classified the associated levels of uncertainties. In China, Jia (1999, 2004) and Zhou and Cui (2006) analyzed the environmental risks brought by GM crops while Chen (2010) argued that they would not have significant impacts on food security. The commercialization of GM crops has been a focus of attention in relation to property rights (Liu and Tian, 2009), ethics (Yang, 2006) and consumers' information rights (Ma and Huang, 2001; Hou and Gu, 2005). The risk of GM management has been an active area of research and this paper's contribution is through the establishing of an innovative three-dimensional model and actor-network theory application.

\section{GM CROPS}

Since the 1994 first commercialized GM tomatoes in US, the global commercialized plantation areas of GM crops have been on the rise (Figure 1) with mainly 4 types of crops: soybeans $(90 \mathrm{mln}$ ha or $77 \%$ of global production), corn $(158 \mathrm{mln}$ ha or $26 \%)$, cotton $(33 \mathrm{mln}$ ha or $49 \%)$ and canola $(31 \mathrm{mln}$ ha or $21 \%)$ (ISAAA, 2009). The expansion of GM areas shows the fast marketization of GM seeds. However, what is of concern is the concentration of seeds within a handful of companies. In 2006 Monsanto, Pioneer Company, Syngenta and Bayer accounted for $41 \%$ of the total global seed sales (Chen, 2010). The highly concentrated market of GM seeds enhances the dependence of Chinese farmers and the global agricultural system on multinational firms. This has not only reduced the diversity of agricultural biological resources, but also intensified the system risks for agriculture, including market power, limiting R\&D and biological risks (Harhoff et al., 2001).

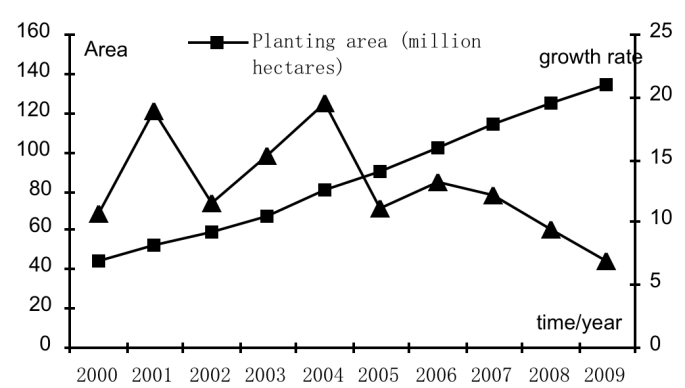

Figure 1. GM crops, James et al., 2003 and ISAAA, 2009

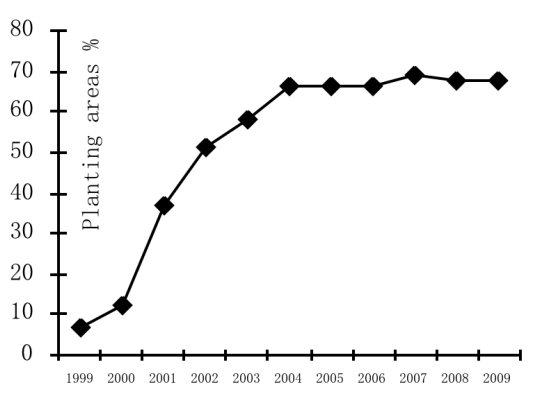

Figure 2. Bt cotton in China, James et al., 2003 and ISAAA, 2009

Although China delayed the plantation of GM crops, its current development is very fast. By 2008, there were 7 domestic GM cops approved for commercial production and 22 foreign approved for import. Currently a small amount of homemade GM tomatoes are planted in Hubei and Guangdong provinces, the frutescens capsicums are limited to Liaoning province and the main GM crop is cotton (Xu et al., 2009). Recently however the plantation of Bt cotton grew rapidly with $70 \%$ of the GM seeds provided by Monsanto (Figure 2). The GM cotton is mainly used as a raw material for textiles, but many farmers in Hebei started to also use the seeds for cooking oil (Xu et al., 2009). Further between 2001 and 2008 China imported 200mln 
Hong et al., Risk analysis of GM crops technology in china

tons of soybeans with $70 \%$ of them containing GM ingredients (Xu et al., 2009). If these GM plants contain any risk material, this would lead to unexpected consequences for which the country is unprepared. 


\section{THREE-DIMENSIONAL MODEL FOR GM TECHNOLOGY RISK ANALYSIS}

Despite the uncertainties surrounding GM technology, its development continues and any risks are socialized every day. First, researchers can consider the level of social harm (including actual and psychological harm) and public response during their R\&D and promotion of the GM technology. Second, according to Roger's (2001) Harm $=f$ (Hazard) model, the harm brought by the GM technology risks is definite, but the functional relationship $\mathrm{f}$ is indefinite. Third, the GM technology risks are also linked to economic and social benefits and generally the higher the risks the higher the expected economic value derived from the crops. However, if the economic value cannot compensate for the damage inflicted on human health, resources, environment and social security, society should have enough reason to reject this type of technology (James et al., 2003).

The three dimensions used to assess the risk associated with GM crops are: social harm, technology maturity and economic benefits (Figure 3). Technology maturity relates to issues such as technology content, scale,

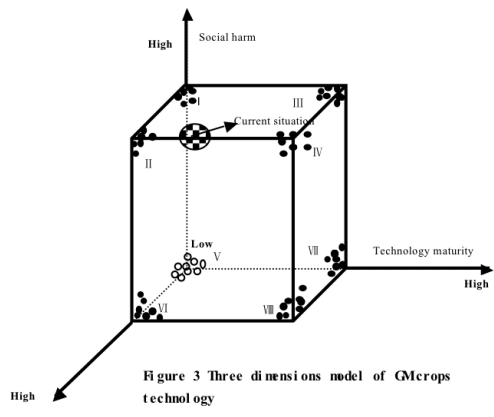

Figure 3. GM assessment model range/sphere of influence, patenting and other research conditions. Generally, lower maturity is expected to bring higher risks and vice versa. Social harm can be actual and/or perceived and is linked to implications related to human health, resources, environment and social stability during marketization. The third dimension represents the economic net results from GM crops technology (the difference between economic benefits and costs caused by investment in GM technology, including enterprise private and social costs). We assume the economic results received from GM crops in time $t$ to be $T R_{t}$, the known enterprise cost is $C C_{t}$ the environmental cost $C U_{t}$ is unknown with a probability of $\mathrm{P}_{\mathrm{t}}$, the discount factors are $D_{t}=1 /(1+r)^{t}$, where $r$ is the social rate of time preference.

Then the economic net results from GM crops technology can be represented by: $\sum D_{t}\left(T R_{t}-C C_{t}-P_{t} x C U_{t}\right)$. The public decision-making about GM depends on a positive value of the net results (James et al., 2003). This does not necessarily represent the level of risk; however it has an overall moderating effect in the model.

There are 8 types of risks (Table 1). First, the social risks (S) of GM technology have broad deep and irreversible characteristics, which means that this dimension plays a decisive role in the model if $\mathrm{S}$ is high. Second, the maturity of GM technology (T) can create risks manifested through social and environmental harm. The GM technology's net economic results (N) do not cause environmental harm on their own but can play a strong coordinating role in the risk level. For example, an "S high T high" situation can create two types of risks, namely "S high T high N low" and "S high T high N high" where the latter has a lower risk than the former. Therefore the 8 categories can be arranged in the following descending sequence according to harmful risk: $\mathrm{H}_{\mathrm{I}}>\mathrm{H}_{\mathrm{II}}>\mathrm{H}_{\mathrm{III}}>\mathrm{H}_{\mathrm{IV}}>\mathrm{H}_{\mathrm{V}}>\mathrm{H}_{\mathrm{VI}}>\mathrm{H}_{\mathrm{VII}}>\mathrm{H}_{\mathrm{VII}}$ (H stands for hazard, representing the level of risk).

Table 1 Types of GM technology risks

\begin{tabular}{|c|c|}
\hline Risk I & Risk II \\
S high T low N low & S high T low N high \\
\hline Risk III & Risk IV \\
S high T high N low & S high T high N high \\
\hline Risk V & Risk VI \\
S low T low N low & S low T low N high \\
\hline Risk VII & Risk VIII \\
S low T high N low & S low T high N high \\
\hline
\end{tabular}

Note: S-social harm, T-technical maturity, N-economic results
In the three-dimensional model, China's GM crops technology is at the high risk of higher social harm, lower technology maturity and lower economic results (Figure 3). From a higher social harm perspective, once GM food becomes daily supply, it would be fatal if there is one risky case happing such as cross-species infection, pathogen drug-resistant or food toxicity. On the other hand, there is little awareness about the issue (Hou and

and $\mathrm{Gu}, 2005$; Huang et al., 2006). The low awareness level causes not only weak self-defense and social supervision power but also provides opportunities for international biological companies to control China's GM food. Most importantly, with its large size irreversible social harm can be produced if GM technology is promoted in China without relevant governance and control. Examples include the allergic reaction to Brazil's soybeans in 1996 and 1998, the StarLink corn incident when soybeans were polluted by GM corn followed by the American Monarch butterfly incident in 1999, the 2001 Mexican corn gene pollution and the 2002 English experiment that caused the GM food DNA to remain in human bodies (Jia, 1999). The US attitude remains positive towards the technology maturity, but the EU is still very cautious. There is an obvious difference in the technological levels between developing and developed countries. There are four stages of research in developed countries: closed greenhouse, semi-closed greenhouse, isolated and fully 
opened experimental field plots, and every step has special requirements. However, in China, research institutes conduct GM research in the laboratories most of which do not have closed or semi-closed conditions and some do not even have the basic conditions for such research (Zhou and Cui, 2006). Also, although China has certain global competitiveness in biotechnology, the GM technology intellectual rights are still far behind developed countries. The monopoly of patent technology has not only delivered low economic benefits from GM technology, but has exposed the country's traditional agriculture to serious challenges. In fact Mooney and Klein (1999) point out serious economic concerns when environmental damage is irreversible. In summary, the position of China's GM crops technology risks in the three dimensions are the outcomes from the game played by all actors in the fields of interest. In order to deal with the high social harm of China's GM technology, this study explores the low technology maturity and low economic net results using actor-networks theory to study the risk management mechanisms.

\section{GM TECHNOLOGY RISKS MANAGEMENT OF ACTOR NETWORKS}

Actor networks reduced the risks in society while providing a platform for constructing the knowledge. The risk management of GM crops technology, to a large extent, can be explored through the supervision of actor networks. In the 1980 the French scholars Latour (1987) and Callon et al. (1986) proposed the Actor-Networks Theory and advocated a whole new frame analysis on sociological research to analyze technology development. In the model of actor-networks, technological development is no longer to be regarded as a mutual fragmented process between the natural non-human actors and social human actors. Non-human actors translate their own benefits to the whole networks through Concatenation of Translation to undertake the technology in the Actor-networks (Figure 4). There are generally four steps during the translation between actors: (1) Problematization - the sponsors (starters) of a new strategy of scientific research propose some solutions that meet other groups' interests to enable an establishment of interests alliance composed of themselves and newcomers; (2) Interessement - the starters take a series of actions to influence the role of other actors defined by the process of Problematization. Various methods and strategies are used and the interessement process tends to damage all the potential competitive cooperation to construct new alliances helpful to achieve the aim of "Obligatory Passage Point" to reshape and consolidate the social structure including social entities and natural entities; (3) Enrollment - a successful Interessement can enable the enrolment of stakeholders. However, once the related bodies are enrolled, they become starters and participants which means their interests are translated into all undertaken plans; (4) Mobilization - if starters have already successfully enrolled other actors to the plans, the initiators will be promoted to become spokespersons and can exercise their rights for the alliance (Callon et al., 1986; Hong et al., 2010).

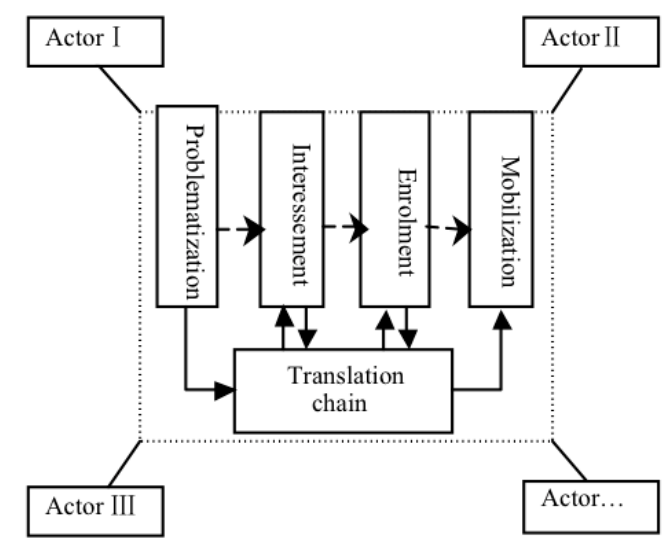

Figure 4. Actor-network construction Source: Hong et al., 2010
For this purpose, Latour (1987) and Callon et al. (1986) proposed a brand new basic model of scientific activities during which actors attempt to establish a long chain of allies through Concatenation of Translation to form a seamless web constructed with sciences, technologies, economies, nature and societies. Among these chains, sponsors are always attempting to realize their hub position as Obligatory Passage Point. Therefore scientific research became an effective power during the competition between alliances while the development of technology is the result of the power.

The risk management structure of GM crops technology within the three dimensions involves governments, enterprises, $\mathrm{R} \& \mathrm{D}$, international actors, the public and many other stakeholders. A

complex actor-network can be formed by these stakeholders (Figure 5) with actors including government actors, economic actors, technology actors, social actors and international actors. Through formulating proper evaluation documents of GM technology development, government regulators will achieve their concatenation of translation in their 'actor-network' and activate various actors of China's GM technology risks management while achieving their strategic position of Obligatory Passage Point to incorporate other actors into the dynamic and heterogeneous network governance to achieve the risks management of GM technology under the three-dimensional model and to change the spatial pattern of the GM technology risks. In figure 5, the government actors are located in the center of the network, where $\rightarrow$ represents the 
Concatenation of Translation process of Obligatory Passage Point (OPP) and the central circle shows the encountered problems during the risks management.

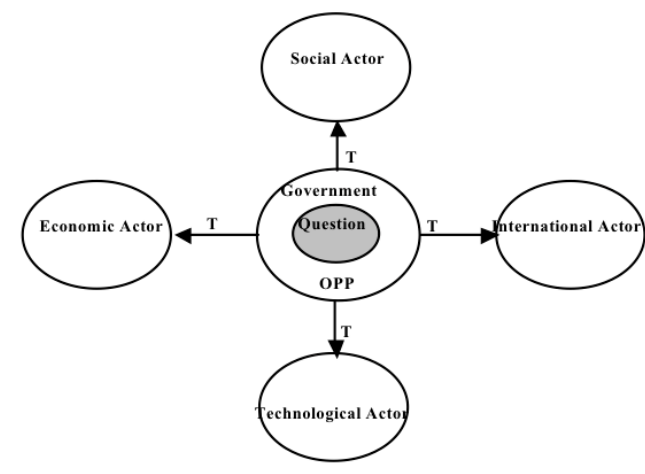

Figure 5. Actor-network
The embedded government actors include state food and drug supervision bureaus, ministry of science and technology, agricultural department, health department, national environmental protection bureau, ministry of commerce, education department and intellectual property bureau etc. The key of risk management from the perspective of actor-network is how the government actors, who are in the Obligatory Passage Point, achieve the balance of interest between the actors during the translation process and then change the risks pattern in the three-dimensional model.

From the perspective of the technology actors, they need to receive financial support from government and enterprise actors but on the other hand, they should promote the degree of GM technology maturity to ensure the safety of GM food. For example, a technological actor was formed by the Chinese Academy of Agricultural Sciences, the Chinese Academy of Social Sciences and the GM technology R\&D institutes of several universities to jointly manage risks. After the GM crops are approved to be allowed in the market, economic actors (such as farmers, manufacturers, distributers and retailers) start to plant, produce and sell GM products. Driven by opportunism, the first purpose of the economic actors is to benefit as much as possible from the process of environmental release of the technology for commercialization. However, these self-driven interests are exposed to pressures from consumers, social media and government regulatory authorities and are constrained by environmental management costs. The social actors mainly composed of consumers, social media and non-governmental organizations (NGOs) are the direct GM crops and risks monitors. They are able to effectively monitor the GM technology risks, but firstly they need to properly understand the characteristics of the lifecycle of GM technology and the level of social harm in its different stages. Finally, the main international actors, such as the World Trade Organization (WTO), World Bank and biological multinational companies will also greatly influence the risks management. For example, WTO is responsible for the international trade coordination for GM foods; however the biological multinational companies to a great extent have been controlling the intellectual property system of GM seeds.

Through the analysis of the actors in the GM technology risks management as well as the examination of the Obligatory Passage Point, it can be inferred that the evolution of actor-networks has its own regularity and convertibility of the government actors' Obligatory Passage Point. During the evolution of the actornetworks of the dynamic and heterogeneous GM technology, government actors will translate imbalanced interests of risks management to balanced common interests of all actors and form a complex network of risks management. These networks include not only governmental, social, technological, economic and international actors (as shown in Figure 5) but also the sub-networks associated with all actors.

Figure 5 shows that in the GM actor-network the core of management with the Obligatory Passage Point is to achieve a balance of network benefits through the process of Concatenation of Translation, which can be divided into 4 stages:

(1) In the stage of Problematization, every actor is involved by the Obligatory Passage Point to work out how to effectively control the GM crops technology risks triggered by high social risks, low-technology maturity and low economic net return. These risks will not be naturally controlled and they need the participation and cooperation among all actors. However whether actors can voluntarily participate in risk management depends on how they estimate any benefits and risks. When the risk management costs for GM technology are greater than the benefits, the actors tend to give up their management plans which could result in an unstable actor-network.

(2) In order to manage the risks successfully, the government actors should achieve the network stability and solidification through the Interessement step of the Concatenation Translation of benefit rights process. Throughout the process of formation, development, stability and solidification, the network of a particular actor depends on how the key point strengthens other actors' role and status during the process of Problematization in order to establish a new alliance system while breaking their potential competitive alliances. 
(3) The Enrollment of stakeholders involves public support for the GM technology. During the process of Interessement, in response to public opposition against GM foods due to lack, insufficient or negative information about safety, the government's role is to react to public concerns and social fear. A strict GM auditing system can make scientific research more socially responsible in laboratories and relate to the broader interests within society. This can further improve the maturity of the technology in order to lower the risk probability or reject the development of the GM technology. In consideration to economic actors and the opportunism of multinational companies, the government should emphasize environmental management and the indirect benefit transformation costs to achieve effective risk management alliances.

(4) The Mobilization stage will depend on the outcomes from the previous three stages and will respond both to any scientific evidence and broader social attitudes towards GM crops technology.

International biological and biotechnology multinational companies can be unscrupulous in inputting products with GM ingredients on the Chinese market. They can also control China's GM seeds and related patents which will influence badly the translation of international actors' benefits to Chinese actors' benefits. The government actors should enhance the publicity and education in GM technology while improving the GM legislation and strengthening the communication and cooperation between actors. On the other hand, the government actors must emphasize the risks management costs of the economic actors during any production of GM food. The government also needs to increase R\&D capabilities and direct technology actors in the development of GM products in order to protect China's independent intellectual rights and reduce the monopoly of GM seeds by international multinational companies. In fact, only the government actors can address the obstacles and problems with a technology that is still at an early stage of development. Finally, the government, under the Mobilization process, will become the voice for social, economic, technological and international actors and ultimately be responsible for risks management.

\section{CONCLUSION}

The GM technology is a very controversial issue. While many parts of the world are strongly objecting and banning its use, others are leaving its fields and markets unprotected and open to be controlled by ambitious profit-seeking and powerful multinational companies. Which way a country will go depends on policy makers and the legislation they approve. This is however not a simple process. The analysis in this paper showed that there are different types and levels of risk associated with the GM technology as well as different actors influencing the developments in the field. China is currently located in the high-risk zone of the developed three-dimensional model, where the high technological uncertainty associated with the potential high social harm shows the urgency for better governance

The Chinese Government needs to have a policy system in place that will allow to properly balance the opportunities and risks associated with the GM technology. Is it a wise option to completely give up GM $\mathrm{R} \& \mathrm{D}$ research? What the actors embedded by interests in this issue need to do is know how to improve the ability of risks management. There is a big gap between China's GM technology level and the world's most advanced achievements. There is also the threat from international actors to prevent China's GM independent intellectual property rights. China needs the R\&D capabilities not to be left behind in the global food race.

However, it is important for the Chinese government to have a system in place that optimizes and promotes the balance of risks/benefits from GM crops. System supply and optimization are effective solutions for the negative externalities of GM technology. This includes a risk assessment system for GM crops technology, GM products R\&D approval system, environmental impacts assessment system, a comprehensive reporting system for tracking and monitoring agricultural GM products' production, processing, operation, import and export activities, text and graphics identification management system. Improvement in the management system and security measures will help achieve a balanced network of benefits to maximize the control of GM technology risks.

Finally, it is vital for the Chinese government to strengthen the communication and cooperation between beneficial bodies and to achieve the actors' networked comprehensive management. They are essential for the government to translate the management benefits of GM technology risks into the self-interests of each actor. Cooperation is necessary within the networks of main bodies of actors and each actor should be treated as having an international background, hence there is a need to have international communication and cooperation. In addition, each actor in China should learn the lessons from the industrialization of the American GM food production and should mirror the European Union's integrity and risk management of food security in order to achieve the required risks management during the network evolution. 


\section{ACKNOWLEDGEMENT}

The first two authors acknowledge the financial support from China's Department of Education (Project No. 09YJA630153) and the large bid project from Social Sciences Fund (Project No. 08\&ZD043). The last two authors acknowledge the financial support of the Australian Research Council.

\section{REFERENCES}

Callon, M., Law, J., Rip, A. (1986). Mapping the dynamics of science and technology: Sociology of science in the real world. Macmillan, Houndmills, UK

Chen, J. (2010) Status quo of GM crops' commercialization and their impacts on crops security and future lessons. Issues in Agricultural Economy, 31(2): 15-20

Harhoff, D., Régibeau, P., Rockett, K. (2001) Some simple economics of GM food. Economic Policy, 16(10): 263-299

Hou, S., Gu, H. (2005) Management of GM food labeling and consumers' consent and selection rights. Studies in Science of Science, 23 (4): 461-466

Hong, J., W. Yu and K. Wang (2010). China's biopharmaceutical industry's evolution and governance of technology based on "actor-network theory". Forum on Science and Technology in China, 26 (11): 55-61.

Huang, J., Jiu, H., Bai, J., Pray, C. (2006) China's urban consumers' awareness and acceptance level of GM food and their willingness to buy. China Soft Science, 21(2): 61-67

International Service for the Acquisition of Agri-biotech Applications (ISAAA, 2009) Global Status of Commercialized Biotech/GM Crops: 2009, the First Fourteen Years, 1996 to 2009. ISAAA Brief 41

James, D.G., Jill, E.H., Nicholas, P., Marni, D.P. (2003). Biotechnology economics. Shanghai Salian Bookshop, Shanghai, China

Jia, S. (1999) Discussion on GM crops' security and its measures. Biotechnology Bulletin, 15(6): 1-7

Jia, S. (2004) Analysis on the environmental risks of GM crops. Agricultural Sciences in China, 37(4): 484-489

Latour, B. (1987) Science in action: How to follow scientists and engineers through society, Harvard University Press, Cambridge, MA

Liu, X., Tian, G. (2009) Rational system for China's GM crops property rights. Yanbian University Bulletin, 42(2): $125-130$

Ma, S., Huang, Z. (2001) Some reflections on the Development of Biotechnology Industry, China Soft Science, 16(1): 61-65

Mooney, S., Klein, K.K. (1999) Environmental concerns and risks of genetically modified crops: Economic contributions to the debate. Canadian Journal of Agricultural Economics, 47(4): 437-444

Paarlberg, R.L. (2000) Governing the GM crop revolution: Policy choices for developing countries. Food, Agriculture, and the Environment Discussion Paper 33. International Food Policy Research Institute, Washington, DC. http://www.ifpri.org/sites/default/files/publications/2020dp33.pdf accessed June 8, 2011

Rogers, M.D (2001) Scientific and technological uncertainty, the precautionary principle, scenarios and risk management. Journal of Risk Research, 4(1): 1-15

Rønning, S.B., Vaïtilingom, M., Berdal, K.G., Holst-Jensen, A. (2003) Event special real-time quantitative PCR for genetically modified Bt 11 maize (Zea Mays). European Food Research and Technology, 216(4): 347-354

Wang, K., Hong J., Marinova, D., Zhu, L. (2009) Evolution and governance of the biotechnology and pharmaceutical industry of China, Mathematics and Computers in Simulation, 79: 2947-2956

Xu J., Sun, C., Chen, X. (2009) Analysis of the status quo of GM food and its trade measures. Chinese Agricultural Science Bulletin, 25(22): 42-46

Yang, T. (2006) Ethical discussion on GM technology: Difficulties and solutions. The Bulletin of Renmin University of China, 20(5): 53-59

Zhang Y., Wu, K., Peng, Y., Guo, Y. (2002) Ecological risks of GM plants. Ecology, 22(11): 1951-1959

Zhou S., Cui Q. (2006) China's GM agricultural products management issues and suggested countermeasures. Forum on Science and Technology in China, 22(1): 60-63 